\title{
The Four Basic Language Skills, Whole Language \& Intergrated Skill Approach in Mainstream University Classrooms in Turkey
}

\author{
Hakan Aydoğan \\ Ph.D.c., International Burch University, Sarajevo \\ E-mail: aydoganh@hotmail.com
}

\section{Associate Professor Azamat A. Akbarov}

Ph.D., International Burch University, Sarajevo

E-mail: azamatakbar@yahoo.com

Doi:10.5901/mjss.2014.v5n9p672

Abstract

The aim of this research is to determine teaching, evaluation, tendency and assessment levels of English language skills and the consistency among these variables of four basic language skills and higlight the importance of 'integrated language skills' in English at tertiary level in preparation classes with language learners. University level instruction is structured more differently than the first and second cycles and usually builds on previously acquired social and academic knowledge The teaching and assessment levels of four basic language skills have been shown by percentages and frequencies and whether there was a significant difference between the basic language skills of the students was analyzed using the appropriate statistical techniques. Questionnaire about the Learning English (QLE) consisted of six subscales: Improving general level of English (items: 1 - 16), Vocabulary learning (items: 17 - 24), Studying grammar (items: 25 - 29), Reading in English (items: 30 - 42), Writing in English (items: 43 - 55), and Speaking in English - outside class (items: 56 - 72). Reliability of all subscales were examined and for that purpose, Cronbach's alpha coefficients of internal consistency was calculated. Our research was conducted via Internet survey tool. Our participants were asked to what extent they agree with each of the items in the questionnaire. The scale we used iss a five-point Likert scale. Raw data was entered into statistical software SPSS for Win, to be analyzed. The findings of this study highlight the importance of developing the right language skills during the critical period of language development. The study showed that trainees have mildly positive attitudes toward the English language, with females slightly being more positive than males. The results indicate that learners do not differ significantly in terms of their difficulties in using daily language skills. This study sheds a light how one of the State universities in Turkey is helping the students to develop English language skills. The research aims to facilitate the learning of English with a proper methodology that will encourage the students at tertiarry level to acquire great competences in English and emphasize the significance of 'integrated language skills' in learning and teaching.

Keywords: Language skills, English language teaching, measurement, assessment and evaluation in language teaching, ESL, (English as a Second Language), ELLs (English Language Learners).

\section{Introduction}

The study places an emphasis on how the tertiary level English teaching education in Turkey aids students to develop the necessary skills as most students complain about the translation and the grammatical paradigms being the most prevalent teaching approach in classes.

The globalisation of English language and an increasing demand for challenging English skills has placed a substantive emphasis on English language teaching in Turkey.Most students in Turkey reach the tertiary level with an educational infrastructure in which 'classroom activities are characterized by the instructors covering the syllabus that students ingest, not leaving much space for questioning and criticism consciously which gives rise to students' blaming the educational system for all. An unconditional obedience to authority is so common overall.

The course books at tertiary level in Turkey focus on all four skills of English, however we can mostly see reading and grammar questions even in the final tests. The students do not hold a chance of interacting in EFL context because of the known inhibiting factors and they feel reluctant or shy to internalise and see it as a way of life.

English is not the medium of instruction except for some private and State universities with some certain percentages. Therefore, many students do not have sufficient language skills to comprehend lectures, textbooks and take 
part in discussions, or generate satisfactory written work where they are the shere memorizers of rules and instructions. A deductive approach to teaching language starts by giving learners rules, then examples, then practice. It is just a teachercentred approach to presenting new content. It is compared with with an inductive approach that starts with examples and asks learners to find out rules which is more learner-centred.

According to the constructivist theory of language learning, foreign language learners build their own learning through experience, interaction and reflection as they constantly interact with new educational situations.( Vygotsky, $1978,1979)$. Learner autonomy consists in becoming aware of, and identifying, one's strategies, needs, and goals as a learner, and having the opportunity to reconsider and refashion approaches and procedures for optimal learning. It may be the case that learner autonomy is best achieved when, among other things, the teacher acts as a facilitator of learning, a counsellor, and as a resource (see Voller, 1997, cited in Benson and Voller, 1997: 99-106).

It goes without saying that various handicaps are identified by the participants in terms of students' all four skills in English which renders the situation compulsory to equip stuents with the critical thinking ability in all four skills required for regular university instruction. These handicaps they encounter consist of some range of challenges such as unmet expectations, academic difficulties, social isolation in the group, adjustment to a new language, culture shock, distress of failure. That is why, acquiring competence in the various English skills and the ability to make use of these skills as a medium of foreign language learning can turn out to be an intimidating experience sometimes. Therefore, after approximately two years of English as a second language (ESL) classes, English language learners (ELLs) at the university level are not yet adequately prepared to perform the most difficult function of literacy skills acquisition-content literacy, the ability to use language to access and master specialized material in content arear across the curriculum ( Vacca \& Vacca, 2005).

When we talk about the four language skills, we are supposed to refer to language acquisition, as well. Krashen (1987) suggested that a high level of anxiety in adults might be the cause of seemingly lower levels of competencies and performance. Therefore, to lower it, Krashen points out that the theory comprehensive input is a necessary provision for second language acquisition to occur (Krashen, 1981, 1982, 1985). Comprehensible input requires repetitions, confirmation, clarifications, modified stuctures used for interactions, and should focus on the 'here and now' (Long, 1983).

Harley (1986) stated that children who learn the language in natural settings as they interact with speakers of the native language at play or other more relaxed social environments are more successful. Linguists are also of the opinion that the age of ELLs at the university level can be a barrier for quick language acquisition. It is mostly referred to as the Critical Period Hypothesis (Brown, 1991a; Dulay, Burt \& Krashen, 1982; Gass \& Selinker, 2001; Krashen, 1987) though Chomsky put this phenomenon to the fact of laterization of the part of the brain that is used for language acquisition.

\subsection{Research Questions}

1. Should we- English teachers use integrated skill approach?

2. Is there any statistically significant gender differences existing in 'Imroving general level of English'?

3. In which skills do the learners use more effective strategies?

\section{Literature Review}

Language educators have long used the concepts of four basic language skills: Listening, Speaking, Reading, Writing. These four language skills are sometimes called the "macro-skills". This is in contrast to the "micro-skills", which are things like grammar, vocabulary, pronunciation and spelling.

The four basic skills are related to each other by two parameters: the mode of communication: oral or written and the direction of communication: receiving or producing the message. Listening comprehension is the receptive skill in the oral mode. When we speak of listening what we really mean is listening and understanding what we hear. Listening comprehension is the receptive skill in the oral mode. When we speak of listening what we really mean is listening and understanding what we hear. Speaking is the productive skill in the oral mode. It, like the other skills, is more complicated than it seems at first and involves more than just pronouncing words.

Speaking is often connected with listening. For example, the two-way communication makes up for the defect in communicative ability in the traditional learning. Temple and Gillet (1984) also emphasize the close relationship between listening and speaking in this way:

Listening cannot be separated from the expressive aspects of oral communication. It is impossible to "teach listening" separately from speaking, or to set aside a portion of the instructional time for listening instruction and ignore it the rest 
of the time.Listening is as much a part of group discussions, dramatic play, or puppetry, for example, as the dialogues and actions created. When children develop their communicative powers they also develop their ability to listen appreciately and receptively. (p.70)

Reading is the receptive skill in the written mode. It can develop independently of listening and speaking skills, but often develops along with them, especially in societies with a highly-developed literary tradition. Reading can help build vocabulary that helps listening comprehension at the later stages, particularly. Writing is the productive skill in the written mode. It, too, is more complicated than it seems at first, and often seems to be the hardest of the skills, even for native speakers of a language, since it involves not just a graphic representation of speech, but the development and presentation of thoughts in a structured way.

The whole-language theoreticians strongly imply that all aspects of language interrelate and intertwine. They further claim that students should be given the opportunity to simultaneously use all language arts (listening, speaking, reading, and writing) in meaningful, functional, and cooperative activities (Carrasquillo, 1993; Farris, 1989; Farris and Kaczmarski, 1988). These activities are often centered around topics that build upon students' background knowledge (Edelsky et al., 1991; Freeman and Freeman, 1994).

In recent years we have seen the emergence of several diverse teaching methodologies. Each one is attracting practitioners who often contend that their particular technique is superior, to the exclusion of the others. However, despite the claims of these proponents, no single methodology adequately addresses the needs of all English-language students. On the contrary, evidence gained from practical experience strongly suggests that the strong points of a variety of methodologies, if skillfully combined, can complement one another, together forming a cohesive, realistic, and highly motivational teaching strategy. (Wilhoit, 1994)

Richards (1983, cited in Omaggio, 1986, p. 126) proposes that the following are the micro-skills involved in understanding what someone says to us. The listener has to:

- retain chunks of language in short-term memory

- discriminate among the distinctive sounds in the new language

- recognize stress and rhythm patterns, tone patterns, intonational contours.

- recognize reduced forms of words

- distinguish word boundaries

- recognize typical word-order patterns

- recognize vocabulary

- detect key words, such as those identifying topics and ideas

- guess meaning from context

- recognize grammatical word classes

- recognize basic syntactic patterns

- recognize cohesive devices

- detect sentence constituents, such as subject, verb, object, prepositions, and the like.

We need to develop our language skills, and specifically, our academic English, in order to: Understand and make the most effective use of our study materials, develop the specialised language and vocabulary relevant to our subject, interpret assignment questions and select relevant and appropriate material for our response, write well-structured and coherently presented assignments, without plagiarism, communicate our needs to our tutors work productively with other students.

As Abdel-Salam El-Koumy (2002) points out about skills-based approach in Teaching and Learning English as a Foreign Language: A Comprehensive Approach;

The skills-based approach drew its theoretical roots from behavioral psychology and structural linguistics. Specifically, it is based on the following principles: (1) The whole is equal to the sum of its parts; (2) There are differences between spoken and written language; (3) Oral language acquisition precedes the development of literacy; (4). Language learning is teacher-directed and fact-oriented; and (5) Students' errors are just like 'sins' which should be eliminated at all costs. In accordance with the above principles, advocates of the skills-based approach view language as a collection of separate skills. Each skill is divided into bits and pieces of subskills. These subskills are gradually taught in a predetermined sequence through direct explanation, modeling and repetition. Furthermore, the skill-building teacher constantly uses discrete-point tests (e.g., multiple choice, true or false, fill in the spaces) to measure the mastery of each subskill before moving to the next. 
Adult learners should be allowed to collaborate during the learning experience; it enhances the learning situation (Green, 1989). Nation (1989) points out that 'one of the most useful procedures is the movement from individual to pair to group to whole class activity'(p.26). The teaching of EFL students should be based on an integrated approach which brings linguistic skills and communicative abilities into close association with each other, this is due to the fact that both language use and language use are important. (Ibrahim, 1993, p.98).

Research has also shown that there is a correlation between word knowledge and reading comprehension (e.g., Barr, 1985; Hoover and Gough, 1990; Kitao, 1988); and that when L2 readers' vocabulary is improved, their reading comprehension is also improved (e.g., Cziko, 1980; Davis, 1989; McDaniel and Pressley, 1986).

\section{Hypotheses}

We defined the following hipotheses, based on results from previous studies and based on logical expectations:

1. Improving general level of English, vocabulary learning, studying grammar, reading in English, writing in English and speaking in English outside class are intercorrelated statistically significant.

2. Other five subscales of Questionnaire about the Learning English explain (in total) statistically significant part of variance of speaking in English outside class, i.e. they are good predictors of speaking in English - outside class.

3. Participants have better skills for vocabulary learning than for studying grammar and this result will be statistically significant.

4. Participants will report that they are better in writing in English than in reading in English and this finding will be statistically significant.

5. We suppose that there will not exist gender differences in average results on six subscales of Questionnaire about the Learning English.

\section{Methodology}

\subsection{Participants}

We took a convenient sample of 149 students. Their mean age was $M=20.97$, with standard deviation $S D=2.52$. Our respondents were from age group ranged from 17 to 27 years old.

Gender distribution of our sample of students is displayed in Figure 1. As we can see, there were 81 females ( $54.4 \%$ of all participants) and 68 males ( $45.6 \%$ of the total sample).

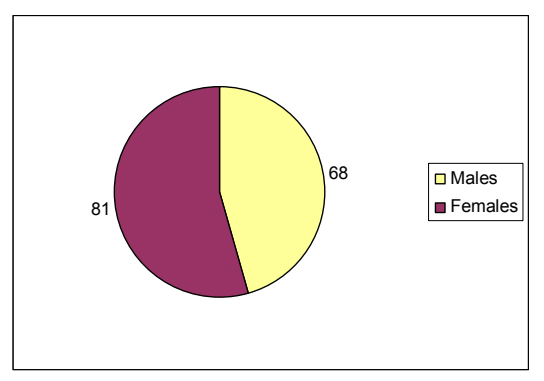

Figure 1. Frequencies of males and females in the sample

\subsection{Instruments}

We applied Questionnaire about the Learning English (QLE), which consisted of six subscales: Improving general level of English (items: 1 - 16), Vocabulary learning (items: 17 - 24), Studying grammar (items: 25 - 29), Reading in English (items: 30 - 42), Writing in English (items: 43 - 55), and Speaking in English - outside class (items: 56 - 72).

We examined reliability of all subscales and for that purpose we calculated Cronbach's alpha coefficients of 
internal consistency. Those coefficients are very high for the following subscales ( $n$ is number of items in the corresponding subscale): Improving general level of English $(n=16, a=.959)$, Vocabulary learning $(n=8, a=.895)$, and Writing in English $(n=13, a=.890)$. We got moderate reliability coefficients for these subscales: Studying grammar $(n=$ $5, a=.821)$, Speaking in English - outside class $(n=17, a=.762)$, and Reading in English $(n=13, a=.734)$.

\subsection{Procedure}

Our research was conducted via Internet survey tool. Our participants were asked how much do they agree with each of the items in the questionnaire. The scale we used was a five-point Likert scale.

Raw data was entered into statistical software SPSS for Win, to be analyzed.

\section{Results and Discussion}

In order to conduct analysis which will allow us to make statistical conclusions about studied variables, we calculated descriptive values for all six subscales (see Table 1).

Table 1: Descriptive statistical values for the subscales of QLE

\begin{tabular}{lcccc}
\hline Subscales & Min & Max & M & SD \\
\hline Improving general level of English & 1.38 & 4.88 & 4.27 & 0.73 \\
Vocabulary learning & 1.50 & 4.88 & 4.25 & 0.68 \\
Studying grammar & 1.00 & 5.00 & 4.12 & 0.72 \\
Reading in English & 1.54 & 4.46 & 3.75 & 0.48 \\
Writing in English & 1.69 & 4.85 & 4.11 & 0.64 \\
Speaking in English (outside class) & 1.82 & 4.35 & 3.56 & 0.53 \\
\hline
\end{tabular}

As we can see (Table 1), students from our sample use the most strategies and skills for improving their general level of English $(\mathrm{M}=4.27)$. Compared to other areas of learning and using English, participants are the least successful in transferring their knowledge and skills to the context outside class $(M=3.56)$. This result we could expect, because students mostly think about school grades, rather than about practical value of their knowledge and learned strategies.

The most variable results were those on the subscale Improving general level of English (SD $=0.73$ ). The most consistent/similar results were for Reading in English (SD $=0.48$ ).

Next, we examined relations between six subscales of QLE. For that purpose, we calculated Pearson's correlation coefficients. The results are shown in Table 2.

We can notice that all of QLE subscales are intercorrelated statistically significant. Therefore, our scale (questionnaire) is very homogenous and participants answered pretty similar to the questions of all subscales.

Table 2: Intercorrelations of SQE subscales

\begin{tabular}{lcccccc}
\hline & $\begin{array}{c}\text { Improving general } \\
\text { level of English }\end{array}$ & $\begin{array}{c}\text { Vocabulary } \\
\text { learning }\end{array}$ & $\begin{array}{c}\text { Studying } \\
\text { grammar }\end{array}$ & $\begin{array}{c}\text { Reading in } \\
\text { English }\end{array}$ & $\begin{array}{c}\text { Writing in } \\
\text { English }\end{array}$ & $\begin{array}{c}\text { Speaking in English } \\
\text { (outside class) }\end{array}$ \\
\hline $\begin{array}{l}\text { Improving general level } \\
\text { of English }\end{array}$ & 1 & $.777^{*}$ & $.738^{*}$ & $.703^{*}$ & $.596^{*}$ & $.452^{*}$ \\
\hline Vocabulary learning & $.777^{*}$ & 1 & $.871^{*}$ & $.732^{*}$ & $.617^{*}$ & $.557^{*}$ \\
\hline Studying grammar & $.738^{*}$ & $.871^{*}$ & 1 & $.729^{*}$ & $.620^{*}$ & $.537^{*}$ \\
\hline Reading in English & $.703^{*}$ & $.732^{*}$ & $.729^{*}$ & 1 & $.756^{*}$ & $.646^{*}$ \\
\hline Writing in English & $.596^{*}$ & $.617^{*}$ & $.620^{*}$ & $.756^{*}$ & 1 & $.745^{*}$ \\
\hline $\begin{array}{l}\text { Speaking in English } \\
\text { (outside class) }\end{array}$ & $.452^{*}$ & $.557^{*}$ & $.537^{*}$ & $.646^{*}$ & $.745^{*}$ & 1 \\
\hline
\end{tabular}

${ }^{*}$ correlation coefficient is significant at level .001

Improving general level of English is (Table 2 ) in high, positive and statistically significant correlations with: vocabulary learning $(r=.777, p<.001)$, studying grammar $(r=.738, p<.001)$, and reading in English $(r=.703, p<.001)$. It is moderately correlated with writing in English $(r=.596, p<.001)$ and Speaking in English - outside class $(r=.452, p<$ .001). 
Vocabulary learning is in high, positive and statistically significant correlation with: studying grammar $(r=.871, p<$ $.001)$ and reading in English $(r=.732, p<.001)$. This subscale is moderately correlated with writing in English $(r=.617, p$ $<.001)$ and speaking in English outside classes $(r=.557, p<.001)$.

Studying grammar is highly correlated with reading in English $(r=.729, p<.001)$ and in moderate positive correlations with writing in English $(r=.620, p<.001)$ and speaking in English outside class context $((r=.537, p<.001)$.

Reading in English is positively and highly correlated with writing in English $(r=.756, p<.001)$ and moderately correlated with speaking in English outside class $(r=.646, p<.001)$.

Finally, writing in English is in a high, positive and statistically significant correlation with speaking in English outside classes $(r=.745, p<.001)$.

Hence, we have completely proved our first hypothesis.

To test our second hypothesis, we conducted multiple regression analysis (MRA). The results are displayed in Table 3.

Table 3: Results of the multiple regression analysis for speaking in English outside class as a criterion

\begin{tabular}{|c|c|c|c|c|c|c|c|}
\hline Predictors & $B$ & $S E B$ & $\beta$ & $T$ & $p$ & $R$ & $R^{2}$ \\
\hline Constant & .711 & .227 & & 3.139 & .002 & \multirow{6}{*}{.767} & \multirow{6}{*}{.588} \\
\hline Improving general level of English & -.134 & .065 & -.186 & -2.055 & .042 & & \\
\hline Vocabulary learning & .165 & .094 & .212 & 1.752 & .082 & & \\
\hline Studying grammar & -.006 & .085 & -.008 & -.073 & .942 & & \\
\hline Reading in English & .194 & .110 & .176 & 1.769 & .079 & & \\
\hline Writing in English & .490 & .068 & .597 & 7.171 & .000 & & \\
\hline
\end{tabular}

Legend: $B$ - unstandardized regression coefficient; SEB - standard error of $B ; \beta$ - standardized regression coefficients; $t$ value of t-test; $\mathrm{df}$ - degrees of freedom, $\mathrm{p}$ - significance, $\mathrm{R}$ - coefficient of multiple correlation, $\mathrm{R}^{2}$ - coefficient of multiple determination

As we can see (Table 3), all five subscales (predictors) explain together $58.8 \%$ of variance of Speaking English outside class and this result is statistically significant $\left(R^{2}=.588, F(5,143)=40.793, p<.001\right)$.

Two of the subscales are statistically significant predictors: Writing in English $(\beta=.597, t=7.171, p<.001)$ and Improving general level of English $(\beta=-.186, t=-2.055, p<.05)$. Vocabulary learning and Reading in English have $p$ values close to the critical value of $p=.05$ (.082 and .079 , respectively), so they can possibly be statistically significant predictors in similar research of other authors in this field of linguistics and educational science.

Hence, we proved the bigger part proved our second hypothesis.

In order to test our third and fourth hypothesis, we applied t-test for paired samples. The results are shown in Table 4 and Table 5.

Table 4: Results of t-test for determining differences between results on Vocabulary learning and Studying grammar

\begin{tabular}{lccccccc}
\hline Subscale (part) & $\mathrm{M}$ & $\mathrm{SD}$ & $\Delta \mathrm{M}$ & $\mathrm{SE}_{\Delta \mathrm{M}}$ & $\mathrm{t}$ & $\mathrm{df}$ & $\mathrm{p}$ \\
\hline Vocabulary learning & 4.25 & 0.68 & 0.13 & 0.03 & 4.571 & 148 & .000
\end{tabular}

Legend: $\Delta \mathrm{M}$ - mean difference; $\mathrm{SE}_{\Delta \mathrm{M}}$ - standard error of the mean difference; $\mathrm{t}$ - value of $\mathrm{t}$-test; df - degrees of freedom; $p$ significance

From Table 4, we can conclude that students are better in using skills and strategies for vocabulary learning ( $M=4.25)$, than for studying grammar $(M=4.12)$. This finding is statistically significant $(t(148)=4.571, p<.001)$. Hence, we proved the third hypothesis.

Table 5: Results of t-test for determining differences between results on Reading in English and Writing in English

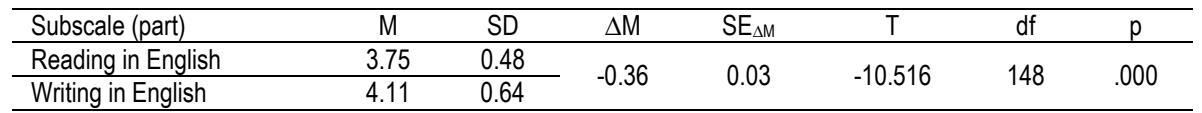

Legend: $\Delta \mathrm{M}$ - mean difference; $\mathrm{SE}_{\Delta \mathrm{M}}$ - standard error of the mean difference; $\mathrm{t}$ - value of $\mathrm{t}$-test; $\mathrm{df}$ - degrees of freedom; $p$ significance 
From Table 5, we conclude that our participants more effectively use strategies and skills related to writing in English (M $=4.11)$, than those of reading in English $(M=3.75)$. This result is, as the previous, statistically significant $(\mathrm{t}(148)=$ $10.516, p<.001$ ), so we proved our fourth hypothesis. Table 6.

To test the fifth proposed hypothesis, we conducted t-test for independent samples. The results are displayed in

Table 6: Results of t-test for exploring gender differences in all six areas of learning and using English

\begin{tabular}{|c|c|c|c|c|c|c|c|c|}
\hline Subscale (part) & Gender & $M$ & SD & $\Delta \mathrm{M}$ & $\mathrm{SE}_{\Delta \mathrm{M}}$ & $T$ & df & $p$ \\
\hline Improving general level of English & $\begin{array}{l}\text { Male } \\
\text { Female }\end{array}$ & $\begin{array}{l}4.40 \\
4.16 \\
\end{array}$ & $\begin{array}{l}0.50 \\
0.87 \\
\end{array}$ & 0.24 & 0.12 & 2.011 & 147 & .046 \\
\hline Vocabulary learning & $\begin{array}{l}\text { Male } \\
\text { Female }\end{array}$ & $\begin{array}{l}4.35 \\
4.16 \\
\end{array}$ & $\begin{array}{l}0.41 \\
0.83\end{array}$ & 0.19 & 0.11 & 1.680 & 147 & .095 \\
\hline $\begin{array}{l}\text { Studying } \\
\text { Grammar }\end{array}$ & $\begin{array}{l}\text { Male } \\
\text { Female }\end{array}$ & $\begin{array}{l}4.16 \\
4.08 \\
\end{array}$ & $\begin{array}{l}0.48 \\
0.86 \\
\end{array}$ & 0.08 & 0.12 & 0.725 & 147 & .470 \\
\hline Reading in English & $\begin{array}{l}\text { Male } \\
\text { Female }\end{array}$ & $\begin{array}{l}3.79 \\
3.72 \\
\end{array}$ & $\begin{array}{l}0.38 \\
0.55 \\
\end{array}$ & 0.07 & 0.08 & 0.883 & 147 & .379 \\
\hline $\begin{array}{l}\text { Writing in } \\
\text { English }\end{array}$ & $\begin{array}{l}\text { Male } \\
\text { Female }\end{array}$ & $\begin{array}{l}4.08 \\
4.14 \\
\end{array}$ & $\begin{array}{l}0.52 \\
0.73\end{array}$ & -0.06 & 0.11 & -0.594 & 147 & .554 \\
\hline Speaking in English (outside class) & $\begin{array}{l}\text { Male } \\
\text { Female }\end{array}$ & $\begin{array}{l}3.53 \\
3.58\end{array}$ & $\begin{array}{l}0.49 \\
0.55\end{array}$ & -0.05 & 0.09 & -0.568 & 147 & .571 \\
\hline
\end{tabular}

The only statistically significant difference is found in Improving general level of English ( $t(147)=2.011, p<.05)$. Males $(M=4.40)$ use strategies and skills for improving general level of English more effectively and more frequently than females $(M=4.16)$.

We did not get statistically significant differences on other subscales: Vocabulary learning $(t(147)=1.680, p>.05)$, Studying grammar $(\mathrm{t}(147)=0.725, \mathrm{p}>.05)$, Reading in English $(\mathrm{t}(147)=0.883, \mathrm{p}>.05)$, Writing in English $(\mathrm{t}(147)=$ $0.594, p>.05)$, and Speaking in English - outside class $(t(147)=-0.568, p>.05)$. That is, we have proved most part of our last hypothesis.

\section{Conclusions}

1) All QLE subscales are in statistically significant correlations with each other.

2) Improving general level of English, Vocabulary learning, Studying grammar, Reading in English, and Writing in English explain 58.8\% of variance of Speaking in English outside class. Improving general level of English and Writing in English are statistically significant predictors of Speaking in English outside class context.

3) Students have developed better skills and strategies for vocabulary learning than for studying grammar.

4) Participants use more effectively strategies and skills for writing in English than for reading in English.

5) Statistically significant gender differences only exist in Imroving general level of English. The average results on other variables (subscales) are pretty similar for males and females.

In our research, the students offered that the practice should be continued and used not only in English lessons but in all other subject matters. They expressed that interaction between teacher-student and student- student enhanced the level of interest, affection and motivation.

As a result of the research, writing skill has been found to be the dominant skill focused on by the students both in teaching and measurement compared to other three language skills. The participants do not reveal a wide spectrum of varied experiences. Significant relationships have been found between the levels of several assessment activities and genders.

There are not statistically significant differences between males and females in speaking and reading comprehension for daily language, as well as reading comprehension for academic language purposes. It is critically important that students' written language skills are assessed at certain intervals and that training programmes are developed for enhancing the written language skills. Even though it is not a vast-scale research, this study has aided to bring out very significant issues regarding the development and assessment of adult language learners at tertiary level in Turkey. 
We conclude from our research that the teachers should encourage the students to become independent learners enhancing the quality of instruction moving away from routine and monotonous activities just for filling time. Thus, our implication from the research is that skill integration is inevitably vital where all language skills are not used separately but instead all language skills are used in every class. Integrating the speaking/listening and writing/ reading classes was informed by Rebecca Oxford's image of of a language class as a tapestery woven of different strands, where the primary skills of speaking, listening, writing, and reading are 'one of the most crucial of these strands' (Oxford 2001, 2).

The integrated-skill approach, as opposed to merely segregated approach, confronts English language learners to authentic language and challenges the learners to interact naturally in the language. If these four skills are separated from one another, a language is taught; however, if they are integrated with each other, authentic communication is taught (Oxford 2001). While doing it, the English teachers are supposed to create materials and topics that meet the students' needs and interests reflecting on their current approach and evaluate the extent to which the skills are integrated. For instance, when we teach writing as a process of drafting, revising and letting them brainstorm, all of those units must be assessed with the students' participation and need analysis, unlike administering a conventional timed essay test.

Our instructional materials, textbooks and technologies we use must promote the integration of listening, reading, speaking, and writing beside the associated skills of syntax, vocabulary and so on. If the tapestery of all four skills is interwoven, English language learners will use them effectively for oral and written communication.

Furthermore, the study results indicate that the integrated-skill approach no matter it is found in content-based or task-based instruction, can be quite motivating to students of all age groups and backgrounds through appropriate tasks. In task-based instruction tasks are defined as activities that can stand alone as fundamental units and that require comprehending, producing, manipulating, or interacting in authentic language while attention is principally paid to meaning rather than form (Nunan, 1989).

The aim is to increase the collaboration and and interaction among students. The theme-based model (Scarcella \& Oxford, 1992) integrates the language skills into the study of a theme and the theme must attract the attention of the learners allowing a wide variety of language skills to be practised. It is a very influential form of content-based instruction in our days and we can use it quite often in our classes.

\section{References}

Abdel-Salam Abdel-Khalek El-Koumy (2002). Teaching and Learning English as a Foreign Language: A Comprehensive Approach, p.12. Suez Canal University, Egypt.

Benson, P. \& Voller, P. 1997. Autonomy and Independence in Language Learning. London: Longman.

Bertelson, P. (1986). The onset of literacy: Liminal remarks. Cognition, 24, 1-30

Brown, H.D. (1991). Breaking the language barrier: Creating your own pathway to success. Yarmouth, ME: Intercultural Press.

Carrasquillo, A.L. (1993) Whole native language instruction for limited-English-proficient students. In Angela Carrasquillo and Carolyn Hedley (Eds.), Whole Language and the Bilingual Learner (pp.3-19). Norwood, NJ: Ablex Publishing Company.

Chomsky, N. (1965). Aspects of theory syntax. Cambridge, MA: The M.I.T. Press.

Dulay, H. , Burt, M., \& Krashen, S. (1982). Language two. Oxford, UK: Oxford University Press.

Farris, P. \& Kaczmarski, D. (1988). Whole language, a closer look. Contemporary Education, 59(2), 77-81

Freeman, D. \& Freeman, Y. 1992). Whole Language for Second Language Learners. Portsmouth, NH: Heinemann.

Gass, S.M., \& Selinker, L. (2001). Second Language Acquisition: An Introductory Course. London, UK: Lawrence Erlbaum.

Gough, P. \& Tunmer, W. (1986). Decoding, reading, and reading disability. Remedial and Special Education, 7, 6-10.

Green, M.L. (1989). 'Methods for teaching non-English speaking adults, Adult Learning, 1(3):25-27.

Harley, B. (1986). Age in Second Language Acquisition. San Diego, CA: College- Hill.

Ibrahim, M. H. (1993). Integrating grammatical structures with communicative practice through situationally based dialogues. Occasional Papers in the Development of English Language Education, 17, 81-106.

Krashen, S.D. (1981). Second Language Acquisition and Second Language Learning. London, UK: Pergamon.

Krashen, S.D. (1987). Applications of psycho-linguistic research to the classroom. In M.H. Long \& J.C. Richards (Eds). Methodology in TESOL: A Book of Readings. Boston: Heinle \& Heinle.

Long, M.H. (1983). Does Second Language Instruction make a Difference? A review of research, TESOL Quarterly, 17(3), 359-382.

McDaniel, M. \& Pressley, M. (1986). Keyword and context instruction of new vocabulary meanings: Effects of text comprehension and memory. Journal of Educational Psychology, 81(2), 204-213.

Nation, P. (1989). 'Speaking activities: Five features', ELT Journal, 43(1): 24-29

Nunan, D. (1989). Designing Tasks for the Communicative Classroom. Cambridge: Cambridge University Press

Omaggio, A. 1986. 'Successful language learners: What do we know about them?', ERIC / CLL News Bulletin, May, 2-3

Oxford, R. 2001. Integrated skills in the ESL/EFL classroom. Washington, DC: ERIC Clearing-house for Languages and Linguistics. ERIC Digest ED456670. www. eric.ed.gov/ ERIC Web Portal/ recordDetail?accno=ED456670. 
Richards, J. (1983). Communicative needs in second and foreign language learning. English Language Teaching Journal (2).

Scarcella, R.C., \& Oxford, R.L. (1992). The Tapestry of Language Learning: The Individual in the Communicative Classroom. Boston: Heinle \& Heinle.

Temple, C. And Gillet, J. W. (1984). Language Arts: Learning Processes and Teaching Practices. Boston: Little Brown and Company Ltd.

Vacca, R., \& Vacca, L. (2005). Content area reading: Literacy and learning across the curriculum (8th ed.). New York: Addison-Wesley. Vygotsky, L.S. (1978). Mind in Society: The Development of higher psychological processes. Cambridge, MA: Harvard University Press. Wilhoit, D. (1994). Enhancing oral skills: A practical and systematic approach. English Language Teaching Forum, 32 (4), 32-36. 